\title{
Properties of Monoclonal Antibodies to the Genus-specific Antigen of Chlamydia and Their Use for Antigen Detection by Reverse Passive Haemagglutination
}

\author{
By MARGARET J. THORNLEY, ${ }^{*}$ SUSANNE E. ZAMZE, ${ }^{+}+$ \\ MARIE D. BYRNE, ${ }^{1}$ MERYL LUSHER ${ }^{1}$ AND ROGER T. EVANS ${ }^{2}$ \\ ${ }^{1}$ Division of Immunology, Department of Pathology, University of Cambridge, \\ Addenbrooke's Hospital. Cambridge CB2 2QQ. UK \\ ${ }^{2}$ Division of Sexually Transmitted Diseases, Clinical Research Centre, Watford Road, Harrow. \\ Middlesex $H A I$ IUJ, UK
}

(Received 1 August 1984; revised 7 September 1984)

The chlamydial genus-specific antigen was extracted with phenol/chloroform/petroleum ether (PCP) from preparations of Chlamydia trachomatis and C. psittaci, and quantities measured using an assay for lipopolysaccharide (LPS). The LPS from C. trachomatis contained $2.2 \%(\mathrm{w} / \mathrm{w})$ of ketodeoxyoctanoic acid. Five IgG monoclonal antibodies reacted in an ELISA with LPS from both species, the antigen being periodate-sensitive and heat-resistant, confirming that all antibodies were against the genus-specific antigen. All the antibodies bound to the PCP extract of $C$. trachomatis on an immunoblot, at a position corresponding to the periodate-Schiff-stained bands of both $C$. trachomatis extract and Salmonella Re-LPS. When linked to trypsin-treated sheep erthrocytes and used in reverse passive haemagglutination tests, all antibodies gave indicator cells capable of detecting chlamydial LPS or crude preparations of chlamydiae grown in McCoy cells, the sensitivity varying with the antibody used. The antibodies varied in IgG subclass (either $\mathrm{IgG}_{2 \mathrm{a}}$ or $\mathrm{IgG}_{3}$ ), and in ability to precipitate in immunodiffusion tests. Two antibodies cross-reacted with one strain of Acinetobacter in ELISA and with Salmonella Re-LPS in both ELISA and immunodiffusion tests. The other three did not react in ELISA with Acinetobacter strains or Salmonella Re-LPS, and none of the five reacted with LPS of E. coli or Pseudomonas morsprunorum.

\section{INTRODUCTION}

The genus-specific antigen of Chlamydia is a glycolipid containing ketodeoxyoctanoic acid (KDO) (Dhir et al., 1971, 1972). Recently, Nurminen et al. (1983), using polyclonal antisera, have shown that this antigen bears a close structural and immunological similarity to LPS of the Re-chemotype (Re-LPS) from certain 'deep-rough' mutants of Salmonella species, and they accordingly described the genus-specific antigen as the LPS of Chlamydia. Caldwell \& Hitchcock (1984), using animal sera, confirmed the findings of Nurminen et al. (1983) of complete cross-reactions between chlamydial and Salmonella Re-LPS, whilst their monoclonal anti-chlamydial LPS antibody did not cross-react with Re-LPS or LPS of several other bacteria when tested by the immunoblotting technique. This antibody was therefore thought to react with a determinant specific to chlamydial LPS. Cross-reactions between the chlamydial genusspecific antigen and strains of Acinetobacter have also been reported (Brade \& Brunner, 1979) but not studied with monoclonal antibodies.

† Present address: Department of Paediatrics, John Radcliffe Hospital, Headington, Oxford, OX3 9DU. UK

Ahbreriations: DOC. sodium deoxycholate; KDO, 2-keto-3-deoxyoctonate: PCP. phenol chloroform/petroleum ether; RPH, reverse passive haemagglutination: SRBC, sheep red blood cells. 
Monoclonal antibodies to the chlamydial genus-specific antigen have been described by Stephens et al. (1982) and Thornley et al. (1983). Our study of the production and characteristics of such monoclonal antibodies, and their possible eventual application in diagnostic methods (Thornley et al., 1983) has been extended to include four additional monoclonal antibodies, characterization of their reactions with chlamydial antigens, a study of cross-reactions with Salmonella Re-LPS and Acinetobacter strains, and further quantitative characterization of the chlamydial genus-specific antigen. The sensitivity of the monoclonal antibodies when coupled to trypsin-treated sheep red blood cells and then used to detect chlamydial antigen by reverse passive haemagglutination (RPH) has also been studied.

\section{METHODS}

Growth of chlamydiae and extraction of the genus-specific antigen. C. trachomatis strains $48 / 80 \mathrm{H}$ and $\mathrm{SA}_{2}(\mathrm{f})$ were cultured in McCoy cells (Evans \& Taylor-Robinson, 1979); $\mathrm{SA}_{2}$ (f) was additionally cultured in egg yolk sacs (Schachter \& Dawson, 1978). Elementary bodies from egg yolk cultures were purified by density centrifugations and enzyme treatment, followed by extraction with $1 \%(\mathrm{w} / \mathrm{v})$ sodium deoxycholate (DOC) to yield the genusspecific antigen (Thornley et al., 1983).

C. trachomatis strain $\mathrm{SA}_{2}$ (f) grown in McCoy cells (a gift from Drs M. Macnaughton and D. Sherwcod, BootsCelltech Diagnostics, Slough, UK) was harvested in distilled water, inactivated by heating at $50^{\circ} \mathrm{C}$ for $1 \mathrm{~h}$, then centrifuged at $20000 \mathrm{~g}$ for $1 \mathrm{~h}$ at $4{ }^{\circ} \mathrm{C}$. The pellet was resuspended in distilled water, treated in an ultrasonic generator (MSE, $100 \mathrm{~W}$ ) for $30 \mathrm{~s}$ at full power and centrifuged at $500 \mathrm{~g}$ for $10 \mathrm{~min}$. The supernatant was retained and freeze-dried before extraction

C. psittari, ovine enzootic abortion (OEA) strain A22, grown in egg yolk sacs, harvested in PBS, $\mathrm{pH} 7 \cdot 3$ and inactivated with formalin $(0 \cdot 2 \%, \mathrm{v} / \mathrm{v})$ was a gift from Dr F. Shand, Wellcome Research Laboratories, Beckenham, UK). PBS contained per litre: $8 \mathrm{~g} \mathrm{NaCl} ; 0 \cdot 2 \mathrm{~g} \mathrm{KCl} ; 1.15 \mathrm{~g} \mathrm{Na}_{2} \mathrm{HPO}_{4} ; 0 \cdot 2 \mathrm{~g} \mathrm{KH}_{2} \mathrm{PO}_{4}$. A suspension of 50 infected egg yolks in $200 \mathrm{ml}$ PBS was dispersed in an Atomix (MSE) used at full power for $5 \mathrm{~min}$, and then centrifuged at $20000 \mathrm{~g}$ for $1 \mathrm{~h}$ at $4^{\circ} \mathrm{C}$. The supernatant, together with a layer of 'egg lipid' on its surface, was discarded and the pellet resuspended in $200 \mathrm{ml}$ PBS. The dispersion and centrifugation were repeated three more times, and the final pellet was resuspended in $150 \mathrm{ml}$ PBS and dispersed in the Atomix. Phospholipase C (Sigma, P-7633; $0.1 \mathrm{mg} \mathrm{m}^{-1}$ ) was added and the mixture incubated at $37^{\circ} \mathrm{C}$ for $90 \mathrm{~min}$, followed by the addition of protease (Sigma, P5130 $0.5 \mathrm{mg} \mathrm{m}^{-1}$ ) and further incubation for $90 \mathrm{~min}$ at $37^{\circ} \mathrm{C}$. The preparation was then disrupted and centrifuged twice as before. The final pellet was dispersed in $50 \mathrm{ml}$ PBS and freeze-dried.

The genus-specific antigen (LPS) was extracted from freeze-dried preparations using phenol/chloroform/petroleum ether (PCP) according to the method of Galanos et al. (1969) with the following modifications. Freeze-dried material was sonicated with $2 \mathrm{ml}$ of the extraction mixture $(5 \mathrm{~min}$, full power, MSE ultrasonic generator, $14 \mathrm{~mm}$ diameter probe). The mixture was centrifuged at $5000 \mathrm{~g}$ for $15 \mathrm{~min}$ and the supernatant retained. Extraction of the pellet was repeated twice and the supernatants combined. Chloroform and petroleum ether were removed by rotary evaporation at $40^{\circ} \mathrm{C}$; distilled water $(10 \mathrm{ml})$ was added to the remaining phenol and the mixture dialysed exhaustively against distilled water at room temperature. The extract from egg yolks contained insolıble "lipid" material which formed a layer on the surface of the supernatant after centrifugation at $5000 \mathrm{~g}$ for $10 \mathrm{~min}$. This layer was removed and the step repeated twice. Extracts from both egg yolk sac and McCoy cells were further treated with a chloroform/methanol mixture, to reduce contamination of the extract by nucleic acid and protein, as follows.

Three volumes of chloroform/methanol $(2: 1)$ were added to the aqueous extract with shaking. The chloroform phase (containing most of the antigen) was retained. An equal volume of distilled water was added and the chloroform removed by rotary evaporation at $40^{\circ} \mathrm{C}$. The antigen was solubilized by ultrasonication ( $2 \mathrm{~min}$, full power). This extraction step was repeated.

Preparations from other organisms. Extracts from strains of Acinetobacter calcoaceticus (NCTC 7844, 10303 and 10305 ) were prepared by heating the bacteria at $100{ }^{\circ} \mathrm{C}$ for $4 \mathrm{~h}$ in $0.9 \%(\mathrm{w} / \mathrm{v}) \mathrm{NaCl}$ (Brade \& Brunner, 1979) as described previously (Thornley et al., 1983).

Deep-rough LPS (Re-LPS) from Salmonella minnesota mR595 was a gift from Dr M. Nurminen, National Public Health Institute, Helsinki, Finland; rough LPS from Escherichia coli ATCC 12408 (Knox et al., 1967) was a gift from Dr Elizabeth Work. Lipopolysaccharides were prepared from strains of Pseudomonas morsprunorum by phenol/water extraction (Westphal \& Jann, 1965).

Preparation of the monoclonal antibodies. The methods used for the monoclonal CF2/47 were described in detail by Thornley et al. (1983). Briefly, Balb/c mice were given a series of injections with viable C. trachomatis strain $\mathrm{SA}_{2}$ (f) elementary bodies, grown in McCoy cells, followed by a series of injections with rifampicin, and a boost with chlamydiae inactivated by ${ }^{60} \mathrm{Co}$ irradiation. After an interval, a second boost with inactivated chlamydiae was followed 3 or $4 \mathrm{~d}$ later by fusion of spleen cells from one mouse with cells of the mouse myeloma cell line 
NSO/U (Clark \& Milstein, 1981), a gift from Dr C. Milstein. Mice for the CF2, CF4 and CF6 fusions were prepared in the same way, except that the intervals from the first injection to the fusion were 96,46 and $181 \mathrm{~d}$, respectively. The methods for fusion, selection and growth of the hybridoma cells were as described by Waldmann \& Milstein (1982). Supernatant fluids were screened for the presence of antibody by the ELISA method and for IgG antibody by the protein A-ELISA method, in both cases using the DOC extract of genus-specific antigen from C. trachomatis strain $\mathrm{SA}_{2}(\mathrm{f})$ as antigen.

The antibody class was confirmed by SDS-PAGE following ${ }^{14} \mathrm{C}$ incorporation (Clark \& Milstein, 1981) and the sub-class by Ouchterlony analysis (Miles reagents). Ascitic fluids were prepared and IgG fractions separated on protein A-Sepharose as described previously (Thornley et al., 1983).

ELISA. This was as described by Thornley et al. (1983), except that antigens in either distilled water or $0.5 \%$ $(w / v)$ DOC in PBS were dried onto the wells of microtitre plates and fixed for $15 \mathrm{~min}$ at room temperature with $50 \%(\mathrm{v} / \mathrm{v})$ ethanol instead of $20 \%(\mathrm{v} / \mathrm{v})$ acetone. All washes and dilutions of antibodies were made with PBS containing $0.055 \%(\mathrm{w} / \mathrm{v})$ Tween 20 (Koch-Light). Bound antibodies were detected with a peroxidase-conjugated anti-mouse immunoglobulin serum (Dako).

A 'protein A-ELISA' method was used to detect IgG antibodies (Crowther \& Abu Elzein, 1980). Details were as described above, except that the test antibodies were diluted in PBS/Tween containing $0.5 \%(\mathrm{v} / \mathrm{v})$ foetal calf serum (Sera-lab, Crawley Down, UK) to prevent non-specific binding of the conjugate. The detection reagent was peroxidase-conjugated protein A (Sigma).

Double immunodiffusion. This was done according to the method of Ouchterlony using $0.6 \%(\mathrm{w} / \mathrm{v})$ agarose in PBS, placed in $3 \mathrm{ml}$ portions on $5 \times 5 \mathrm{~cm}$ glass plates. Wells $2.5 \mathrm{~mm}$ in diameter and $5 \mathrm{~mm}$ apart contained $10 \mu \mathrm{l}$ of reagents. Antigens were diluted in distilled water containing $0 \cdot 2 \%(\mathrm{w} / \mathrm{v})$ SDS and placed in a central well. Ascitic fluid preparations (undiluted) of the monoclonal antibodies were added to the surrounding wells. After $18 \mathrm{~h}$ at $4{ }^{\circ} \mathrm{C}$, plates were examined by dark ground illumination, washed and stained with Coomassie blue.

Chemical methods. Chlamydial LPS was oxidized with sodium periodate $(0.05 \mathrm{M})$ in distilled water $(0.5 \mathrm{ml})$ at room temperature for $2 \mathrm{~h}$ in the dark, and was terminated by the addition of $10 \mu \mathrm{l}$ ethanediol. Modified LPS was diluted and used as antigen in ELISA.

Concentrations of chlamydial LPS were estimated using the carbocyanine dye spectral shift assay of Janda \& Work (1971). Re-LPS from S. minnesota was used as the standard. KDO was detected using thiobarbituric acid (Osborne, 1963).

$S D S-P A G E$. Slab gel electrophoresis was done according to the method of Laemmli (1970) using a final acrylamide concentration in the separating gel of $12 \%(\mathrm{w} / \mathrm{v})$ and gels of dimensions $16 \times 14 \times 0.1 \mathrm{~cm}$. Electrophoresis $(20 \mathrm{~mA}$, constant current) was continued until the dye front had migrated $10 \mathrm{~cm}$ into the separating gel. LPS was visualized in the gels using either the periodate-Schiff stain or the silver stain of Tsai \& Frasch (1982).

Immunoblotting (Western blotting). After separation on the SDS-polyacrylamide slab gels, LPS was electrophoretically transferred (blotted) from the gels onto nitrocellulose sheets according to the method of Towbin et al. (1979), in a Bio-Rad Trans-Blot electrophorectic transfer cell. The nitrocellulose sheet was placed nearest to the anode and electrophoresis was carried out at $40 \mathrm{~V}, 130 \mathrm{~mA}$ for $18 \mathrm{~h}$. IgG preparations of monoclonal antibodies, purified from supernatants of tissue cultures, were used for antigen detection. The nitrocellulose sheet

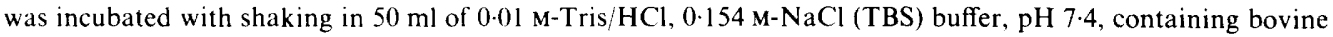
haemoglobin Type II (Sigma; $30 \mathrm{~g}^{-1}$ ) for $4 \mathrm{~h}$ at room temperature. The nitrocellulose was then divided into strips and these were incubated separately either with a mixture of all five monoclonal antibodies, each at a concentration of $1 \mu \mathrm{g} \mathrm{ml}^{-1}$ in $10 \mathrm{ml}$ TBS buffer with haemoglobin, or, to investigate the reaction of the antigen with single monoclonal antibodies, with $50 \mu \mathrm{g}$ of a single monoclonal antibody in $10 \mathrm{ml}$ TBS with haemoglobin. Incubation was for $18 \mathrm{~h}$ at $4{ }^{\circ} \mathrm{C}$ with shaking. Normal mouse IgG $(50 \mu \mathrm{g}$ in $10 \mathrm{ml})$ was used as a control.

Strips were washed in $10 \mathrm{ml}$ TBS, followed by $10 \mathrm{ml}$ TBS containing $5 \mu$ l Nonidet P40 detergent and finally by one wash of $10 \mathrm{ml}$ TBS. Each wash was with shaking for $20 \mathrm{~min}$. The strips were then incubated for $4 \mathrm{~h}$ at room temperature with a rabbit anti-mouse immunoglobulin (Sigma) diluted 1 in 300 in TBS/haemoglobin then washed as described above. Finally they were incubated for $18 \mathrm{~h}$ at $4{ }^{\circ} \mathrm{C}$ with sheep anti-rabbit immunoglobulin conjugated to horse radish peroxidase (a gift from Dr Peter Jackson, Department of Clinical Biochemistry, University of Cambridge, UK) diluted 1 in 50 in TBS/haemoglobin. The strips were washed as described above and developed with a solution $\left(0 \cdot 2 \mathrm{~g}^{-1}\right)$ at $3,3^{\prime}$-diaminobenzidine tetrahydrochloride in TBS containing $200 \mu \mathrm{l}$ hydrogen peroxide $(100 \mathrm{vol}$.). The reaction was stopped by repeated washing with distilled water.

Reverse passive haemagglutination $(R P H)$. Sheep red blood cells were treated as described by Scott et al. (1981), with either trypsin (Difco grade 1:250) or chymotrypsin from bovine pancreas (Sigma C-4129) at a final concentration of $0.5 \mathrm{mg} \mathrm{ml}^{-1}$. IgG preparations of the monoclonal antibodies, or normal mouse IgG, at concentrations of 0.25 or $0.5 \mathrm{mg} \mathrm{ml}^{-1}$ in $0.15 \mathrm{M}-\mathrm{NaCl}$ were linked to the enzyme-treated sheep red blood cells by chromic chloride, as described by Scott et al. (1981). Coupled cells prepared in this way were either used fresh (for up to 2 weeks after preparation) or were stabilized with glutaraldehyde (Cranage et al., 1983). 
For RPH tests, antigens were diluted in PBS, pH 7.3, containing 0.005\%(w/v) Tween 20 (Koch-Light). Portions of $25 \mu \mathrm{l}$ of each dilution were added to $\mathrm{U}$-shaped wells of polystyrene microtitre plates (Sterilin). One drop (about $30 \mu \mathrm{l})$ of a $1 \%(\mathrm{v} / \mathrm{v})$ suspension of fresh or glutaraldehyde-treated coupled red cells in PBS was added to each well and the plates were agitated for $30 \mathrm{~s}$ on a micro-mixer (Triyo-Bussan). The haemagglutination patterns were read after $90 \mathrm{~min}$.

PCP extracts of chlamydial LPS were diluted and tested directly, but crude preparations of McCoy cell-grown C. trachomatis strains were pre-treated by heating at $100{ }^{\circ} \mathrm{C}$ for $5 \mathrm{~min}$ in PBS containing $0 \cdot 1 \%$ (w/v) SDS and $20 \mathrm{~mm}$-EDTA, pH 8.2, before testing.

\section{RESULTS}

\section{Production of monoclonal antibodies}

With the mouse inoculation schedule described, the monoclonal antibodies to the chlamydial group-specific antigen were predominantly IgM. However, there were indications that longer intervals between priming and fusion resulted in a higher proportion of IgG-producing clones. In the CF6 fusion, both types of ELISA were used at an early stage in the testing of cell lines. Selection was made of lines giving a positive protein A-ELISA and presumed to be IgG producers, and some which were negative with protein A but positive with the normal ELISA. The cell lines eventually isolated proved to be four $\mathrm{IgG}$ producers (three $\operatorname{IgG}_{2 \mathrm{a}}$ and one $\mathrm{IgG}_{3}$ ) and four IgM producers, and all had been correctly indicated by the protein A-ELISA.

The antibodies studied in detail and described here were all IgG, which gave high readings in ELISA and included CF2/47, some properties of which have already been reported (Thornley $e t$ al., 1983).

\section{Properties of LPS extracts}

The genus-specific antigen prepared by extraction with PCP allowed the application of tests which could not be used on a DOC extract.

PCP extracts from both $C$. trachomatis and $C$. psittaci produced spectral shifts in the carbocyanine dye assay for LPS (Janda \& Work, 1971) giving a dye adsorption maximum of $460 \mathrm{~nm}$, as did Salmonella Re-LPS, which was used as the standard. The assay was used for detection and estimation of small quantities of LPS. The amounts of LPS obtained from freezedried preparations of egg-grown $C$. psittaci, OEA strain and tissue-culture grown $C$. trachomatis $\mathrm{SA}_{2}(\mathrm{f})$ were $0.08 \%(\mathrm{w} / \mathrm{w})$ and $1-2.4 \%(\mathrm{w} / \mathrm{w})$, respectively.

The LPS contained KDO, as indicated by the production of an absorption spectrum in the thiobarbituric acid assay indentical with that of authentic KDO. LPS from tissue culture grown C. trachomatis contained $2 \cdot 2 \%(\mathrm{w} / \mathrm{w}) \mathrm{KDO}$.

\section{ELISA}

Extracts obtained with PCP from both $C$. trachomatis and $C$. psittaci were used as antigen at 5 and $1 \mu \mathrm{g} \mathrm{ml}^{-1}$ in ELISA tests, and gave binding of monoclonal antibodies which was comparable to, or higher than, that shown by a DOC extract, previously used as an arbitrary standard for comparison of experiments but containing an unknown amount of LPS (Table 1). The PCP extract of $C$. psittaci from egg-grown material gave higher readings at the lower concentration, probably because of the dilution of lipid material, which prevented adsorption of the antigen to the ELISA plates. The monoclonal antibodies CF6/J12, CF6/L13 and CF6/L5 gave higher readings than CF2/47 or CF4/B2 with all chlamydial LPS preparations.

When the PCP extract of $C$. trachomatis had been treated with periodate, binding of all monoclonals was much reduced, whereas heating at $100^{\circ} \mathrm{C}$ for $1 \mathrm{~h}$ gave no change in subsequent reactions. These facts, together with the binding of all monoclonals to extracts of both $C$. trachomatis and $C$. psittaci LPS, confirmed that their reaction was with the genus-specific antigen.

The sensitivity of the ELISA as a means of detecting chlamydial antigen was not fully investigated, but in one test, using as antibody a $1: 10$ dilution of a tissue culture supernatant of CF6/J12, a PCP extract of $C$. trachomatis LPS was detectable in a dilution containing $30 \mathrm{ng} \mathrm{ml}^{-1}$ but not at $3 \mathrm{ng} \mathrm{ml}^{-1}$. 
Table 1. ELISA assay of binding of monoclonal antibodies to chlamydial and other LPS preparations

\begin{abstract}
LPS preparations were in distilled water. apart from C.trachomatis DOC extract (used at $1: 10$ dilution in $0.5 \%, \mathrm{w} / \mathrm{v}$ DOC). Monoclonal antibodies were tested in tissue culture supernatants, diluted $1: 10$ in PBS with $0.05^{\circ}$, Tween 20, and compared with the tissue culture medium [Iscove's Modified Dulbecco's medium (Gibco) $+5^{\circ}$. v/v. foetal calf serum (Sera-lab)] also diluted 1:10. Controls (not shown) for $0.5^{\circ}$ DOC and distilled water dried on wells gave readings $\leqslant 0.02$ for all monoclonals. A preparation of PSe'udomonas morsprunorum LPS, tested at 5 and $1 \mu \mathrm{g} \mathrm{ml} \mathrm{m}^{-1}$. gave negative results (not shown) with all monoclonals. Results of a typical experiment are shown: all observations were repeated three or more times.
\end{abstract}

\begin{tabular}{|c|c|c|c|c|c|c|c|c|c|c|}
\hline \multirow{3}{*}{$\begin{array}{l}\text { Monoclonal } \\
\text { antibody }\end{array}$} & \multirow{3}{*}{$\begin{array}{r}\text { Concn } \\
\left(\mu \mathrm{g} \mathrm{m}^{-1}\right)\end{array}$} & \multicolumn{9}{|c|}{$A_{492}$ with LPS from: } \\
\hline & & \multicolumn{2}{|c|}{$\begin{array}{l}\begin{array}{l}\text { C. trachomatis } \\
\text { (PCP extract) }\end{array}\end{array}$} & \multicolumn{2}{|c|}{ 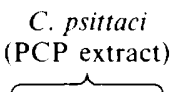 } & \multirow[t]{2}{*}{$\begin{array}{l}\text { C. trachomatis } \\
\text { (DOC extract) }\end{array}$} & \multicolumn{2}{|c|}{$\begin{array}{c}\begin{array}{c}\text { Salmonella } \\
\text { Re-LPS }\end{array} \\
\end{array}$} & \multicolumn{2}{|c|}{$\begin{array}{l}\begin{array}{c}\text { E. coli } \\
\text { LPS }\end{array} \\
\end{array}$} \\
\hline & & 5 & 1 & 5 & 1 & & 5 & 1 & 5 & 1 \\
\hline $\mathrm{CF} 2 / 47$ & & $1 \cdot 18$ & 0.63 & $0 \cdot 82$ & $1 \cdot 18$ & 0.86 & $0 \cdot 19$ & $0 \cdot 14$ & $0 \cdot 01$ & $0 \cdot 03$ \\
\hline $\mathrm{CF} 4 / \mathrm{B} 2$ & & 1.09 & 0.48 & 0.74 & $1 \cdot 14$ & 0.48 & 0.08 & 0.09 & 0.03 & $0 \cdot 02$ \\
\hline $\mathrm{CF} 6 / \mathrm{J} 12$ & & 1.78 & 1.06 & $1 \cdot 14$ & 1.95 & 1.72 & $0 \cdot 02$ & 0.02 & 0.02 & 0.00 \\
\hline CF6/L13 & & 1.98 & $1 \cdot 48$ & $1 \cdot 25$ & 1.88 & 1.72 & 0.02 & 0.02 & $0 \cdot 01$ & $0 \cdot 04$ \\
\hline CF6/L5 & & $>2$ & $1 \cdot 17$ & $1 \cdot 50$ & 1.98 & 1.78 & 0.02 & 0.02 & 0.02 & 0.06 \\
\hline issue culture & dium & 0.01 & $0 \cdot 00$ & $0 \cdot 01$ & $0 \cdot 01$ & 0.01 & 0.01 & 0.01 & 0.02 & $0 \cdot 01$ \\
\hline
\end{tabular}

\title{
SDS-PAGE and immunoblotting
}

LPS preparations from C.trachomatis, $C$. psittaci and Re-LPS from Salmonella each revealed one fast-migrating band after electrophoresis through $12 \%(\mathrm{w} / \mathrm{v})$ SDS-polyacrylamide and staining with periodate -Schiff. Each LPS had the same electrophoretic mobility, migrating just a little more slowly than the dye front.

Immunoblotting revealed a single band corresponding to that detected on the gel with periodate-Schiff. Blots of $C$. trachomatis and $C$. psittaci LPS were detected using a mixture of monoclonals as the primary antibody; both yielded identical bands. Blots of $C$. trachomatis LPS were detected with each monoclonal antibody individually, all five monoclonals giving identical bands, but with varying intensity. Blots so obtained were most intense with $\mathrm{CF} 6 / \mathrm{L} 13$ and CF6/J12, and least intense with CF2/47 and CF4/B2.

\section{Immunodiffusion}

Ascitic fluids containing the monoclonal antibodies $\mathrm{CF} 2 / 47$ and $\mathrm{CF} 4 / \mathrm{B} 2$ reacted with $C$. trachomatis and $C$. psittaci LPS in double immunodiffusion to form single precipitin lines. Precipitin lines fused to show a reaction of complete identity between the two monoclonals. Monoclonal antibodies CF6/J12 and CF6/L5 did not cause precipitation.

\section{Reverse passive haemagglutination ( $R P H)$}

PBS containing Tween 20 at $0 \cdot 005 \%(\mathrm{w} / \mathrm{v})$ was routinely used to dilute the antigen for RPH tests with either fresh or glutaraldehyde-stabilized cells in suspension in PBS. This enabled cells which exhibited some degree of autoagglutination in PBS alone to be used.

A PCP extract of $C$. psittaci LPS was titrated against indicator cells linked to each of four different monoclonal antibodies and the resulting values for LPS concentration at the end-points (Table 2) showed a wide range in sensitivity. Of the two most sensitive indicators, trypsintreated sheep red blood cells (SRBC) coupled to CF6/J12 could be used in the absence of Tween 20 in the diluent, whilst CF6/L13 coupled to chymotrypsin-treated SRBC exhibited autoagglutination in PBS alone, but resulted in very sensitive cells when diluted with 
Table 2. Sensitivities of indicator cells linked to $\operatorname{Ig} G$ of various monoclonal antibodies in RPH of an extract of C. psittaci

Results are given with the range of values in parentheses.

$\begin{array}{lcc}\begin{array}{c}\text { Monoclonal } \\ \text { antibody } \\ \begin{array}{c}\text { coupled } \\ \text { to SRBC }\end{array}\end{array} & \begin{array}{c}\text { Chlamydial LPS concn } \\ \text { at end-point of titration } \\ \left(\mathrm{ng} \mathrm{m}^{-1}\right)\end{array} \\ \text { CF2/47 } & 6 \cdot 2(3 \cdot 1-12 \cdot 5) & 200 \quad(100-200) \\ \text { CF4/B2 } & 25(12 \cdot 5-50) & 2000 \dagger \\ \text { CF6/J12 } & 1 \cdot 6(0 \cdot 8-1 \cdot 6) & 6 \cdot 2(3 \cdot 1-9 \cdot 2) \\ \text { CF6/L13 } & 0 \cdot 4(0 \cdot 2-0 \cdot 4) & 3 \cdot 1(1 \cdot 6-3 \cdot 1)\end{array}$

* Chymotrypsin-treated SRBC were coupled to CF6/L13, and trypsin-treated SRBC to all other antibodies. + One observation only. All other values were obtained with two or more preparations of antibody-coupled SRBC. Stabilized cells coupled to CF6/J12 and CF6/L/3 were prepared in three different experiments, using $S R B C$ from two different sheep, and tested after storage for periods from 1 to $98 \mathrm{~d}$.

PBS/Tween. When fresh, these latter cells detected $0.4 \mathrm{ng} \mathrm{LPS} \mathrm{ml}^{-1}$ at the titration end-point which was equivalent to $10 \mathrm{pg}$ antigen per well.

Glutaraldehyde stabilization of indicator cells coupled to CF6/J12 or CF6/L13 usually resulted in the reduction of sensitivity by a factor of 4 or 8 , as seen in Table 2, giving stabilized cells which detected chlamydial LPS at concentrations of 3 or $6 \mathrm{ng} \mathrm{ml}^{-1}$. Such cells retained unchanged activity for at least 3 months.

Crude preparations of $C$. trachomatis grown in McCoy cells gave very low titres when tested by RPH without pre-treatment. Heating at $100^{\circ} \mathrm{C}$ for $5 \mathrm{~min}$ in PBS/SDS/EDTA, pH 8.2, yielded higher titres than those obtained after ultrasonic vibration, as used by Thornley et al. (1983). Results obtained with stabilized cells for the heated preparations are related to the numbers of inclusion-forming units (i.f.u) initially present (Table 3 ). Considerable variation between two preparations of $C$. trachomatis strain $48 / 80 \mathrm{H}$ was found. In tests with indicator cells plus $\mathrm{CF} 6 / \mathrm{J} 12$, antigen concentrations between 9 and 469 i.f.u. per well were detected at the endpoints and between 2 and 59 i.f.u. per well in tests with cells plus CF6/L13.

\section{Cross-reactions}

The monoclonal antibodies CF2/47 and CF4/B2 cross-reacted in ELISA with Salmonella ReLPS, although binding to Re-LPS was less than to chlamydial LPS when both antigens were tested at the same concentrations (Table 1). Antibodies CF6/J12, CF6/L13 and CF6/L5 did not react with Re-LPS in any ELISA tests.

Antibodies CF2/47 and CF4/B2 gave reactions in ELISA with both cell suspensions and extracts of Acinetobacter calcoaceticus NCTC 10303, and, additionally, CF2/47 reacted with NCTC 7844. No other antibodies listed in Table 1 gave any binding to these strains, and none reacted with Acinetobacter NCTC 10305.

Cross-reactions were also observed in immunodiffusion tests between monoclonal antibodies CF2/47 and CF4/B2 and Salmonella Re-LPS, where single precipitation lines were observed. No cross-reactions were observed in ELISA or immunodiffusion tests with E. coli LPS, and none were found in ELISA with Pseudomonas morsprunorum LPS.

In RPH tests, Salmonella Re-LPS at concentrations of $1 \mu \mathrm{g} \mathrm{ml}^{-1}$ or more caused some nonspecific agglutination of freshly prepared indicator cells; at $0.5 \mu \mathrm{g} \mathrm{ml}^{-1}$ or less, all tests were negative. Glutaraldehyde-stabilized cells gave no non-specific reactions with Re-LPS at $5 \mu \mathrm{g} \mathrm{ml}^{-1}$, and all tests, including those with indicator cells linked to CF2/47 and CF4/B2, were negative.

Extracts of Acinetobacter strains NCTC 7844, 10303 and 10305, tested neat and diluted gave negative results in RPH with the stabilized indicator cells listed in Table 2, and with freshly prepared cells linked to $\mathrm{CF} 2 / 47$ and $\mathrm{CF} 4 / \mathrm{B} 2$. 

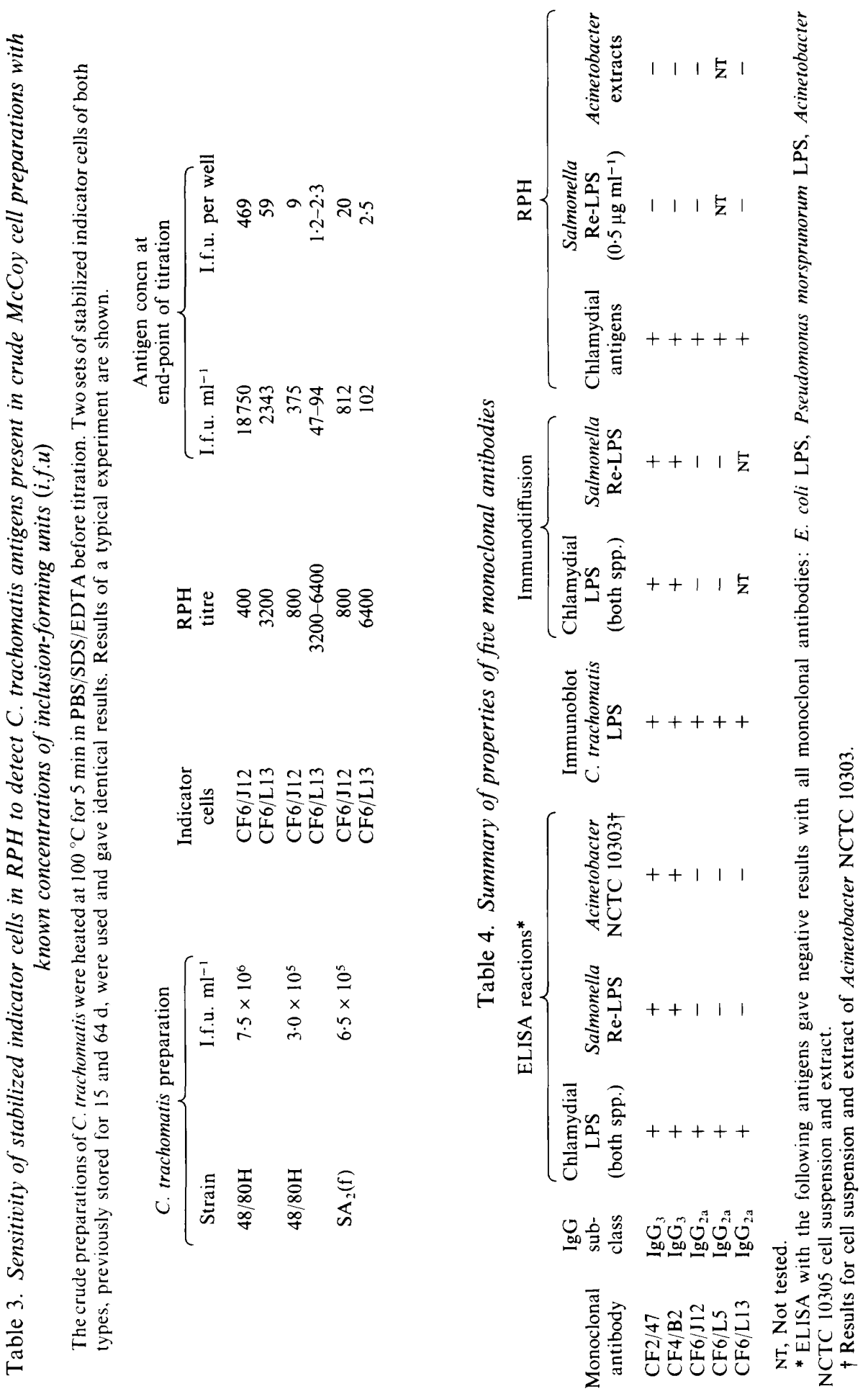


\section{DISCUSSION}

The genus-specific antigen of Chlamydia spp. has been extracted with PCP from both tissueculture grown $C$. trachomatis as described by Nurminen et al. (1983), and from egg-grown $C$. psittaci. Chlamydial LPS could be estimated in small quantities in these extracts, by the carbocyanine dye spectral shift assay which has not previously been applied to chlamydial material. Salmonella Re-LPS, shown to resemble chlamydial LPS in several properties (Nurminen et al.. 1983), was thought to be an appropriate standard, and both caused shifts in the absorption maximum of the dye to $460 \mathrm{~nm}$.

In general, properties of the extracted genus-specific antigen were as previously reported. It was soluble in chloroform/methanol and diethyl ether, was of limited solubility in water, and contained KDO or a closely related compound. The KDO represented $2 \cdot 2 \%(\mathrm{w} / \mathrm{w})$ of the L.PS in an extract from tissue-culture grown $C$. trachomatis, a rather lower figure than those of approximately $5 \%$ (Nurminen et al., 1983) or $8.8 \%$ (Caldwell \& Hitchcock, 1984) reported previously. SDS-PAGE confirmed that the chlamydial LPS was the same or similar in molecular size to Salmonella Re-LPS as was reported by Nurminen et al. (1983).

The properties of the monoclonal antibodies are summarized in Table 4. All reacted with chlamydial LPS from both species, the antigenic determinant(s) being heat-resistant and periodate-sensitive, confirming that the reaction was with the genus-specific antigen. The binding could be demonstrated by immunoblotting, as previously shown for polyclonal sera by Nurminen et al. (1984) and by Caldwell \& Hitchcock (1984) for their monoclonal antibody. The antibodies differed in their ability to give a precipitin line in immunodiffusion tests (Table 4). When linked to trypsin-treated sheep erythrocytes, all would detect chlamydial antigens in RPH tests.

The pattern of cross-reactions shown in Table 4 indicates the existence of at least two antigenic determinants on the chlamydial LPS. Monoclonal antibodies CF6/J12, CF6/L5 and CF6/L13 showed no cross-reactions with Salmonella Re-LPS, E. coli or Pseudomonas LPS, nor with three strains of Acinetobacter, indicating that at least one determinant of chlamydial LPS is not shared with these other organisms. The monoclonal anti-chlamydial LPS described by Caldwell \& Hitchcock (1984) also failed to reacted with Salmonella Re-LPS, but its reaction with Acinetobacter was not described.

The cross-reaction between chlamydial LPS, Re-LPS and Acinetobacter NCTC 10303 shown by monoclonal antibodies CF2/47 and CF4/B2 indicates the existence of a determinant common to all three organisms. This has presumably been involved in the cross-reaction revealed by human and animal sera between chlamydiae and Acinetobacter (Brade \& Brunner, 1979) and between chlamydial LPS and Re-LPS (Nurminen et al., 1983; Caldwell \& Hitchcock, 1984).

Nurminen et al. (1984) found that the cross-reacting component of an Acinetobacter strain was located in a part of its LPS. Since LPS was not measured in our Acinetobacter extracts, it is not known how much significance should be given to the negative results obtained with strain NCTC 10303.

The absence of cross-reactions in RPH tests of Acinetobacter extracts with cells coupled to CF2/47 and CF4/B2 confirmed previous tests with CF2/47 (Thornley et al., 1983) but was surprising since both monoclonal antibodies reacted with Acinetobacter NCTC 10303 in ELISA tests.

$\mathrm{RPH}$ proved to be a sensitive method for the detection of chlamydial antigen, as in other systems, e. g. the measurement of $\operatorname{IgE}$ (Scott et al., 1982). The modification of adding a very low concentration of Tween 20 to the diluent allowed the use of slightly clumped cells, and this apparently increased the sensitivity. The provision of stabilized cells means that this method might be useful in tests for chlamydial antigens in human and veterinary samples.

We are grateful to the people mentioned who made gifts of cells, chlamydial and other preparations and to Professor R. R. A. Coombs and Dr D. Taylor-Robinson for their support and encouragement, and to Dr H. Waldmann and colleagues for their help and advice with monoclonal antibody techniques. This work was supported by grants from the Medical Research Council to M. J. T., S. E. Z., M. D. B. and M. L. 


\section{REFERENCES}

Brade. H. \& BrunNer, H. (1979). Serological crossreactions between Acinetobacter calcoaceticus and chlamydiae. Journal of Clinical Microbiology 10, 819 822.

Caldwell, H. D. \& Hitchcock, P. J. (1984). Monoclonal antibody against a genus-specific antigen of Chlamydia species: location of the epitope on chlamydial lipopolysaccharide. Infection and Immunit. 44, 306-314.

ClaRK, M. R. \& Milstein, C. (1981). Expression of spleen cell immunoglobulin phenotype in hybrids with myeloma cell lines. Somatic Cell Genetics 7, 657666.

Cranage, M. P., Gurner, B. W. \& Coombs, R. R. A. (1983). Glutaraldehyde stabilization of antibodylinked erythrocytes for use in reverse passive and related haemagglutination assays. Journal of Immunological Methods 64, 7-16.

Crowther, J. R. \& Abu Elzein, E. M. E. (1980). Detection of antibodies against foot and mouth disease virus using purified Staphylococcus A protein conjugated with alkaline phosphatase. Journal of Immunological Methods 34, 261-267.

Dhir, S. P., Kenny, G. E. \& Grayston, J. T. (1971). Characterization of the group antigen of Chlamydia trachomatis. Infection and Immunity 4, 725-730.

Dhir, S. P., HaKomori, S., KeNNY, G. E. \& Grayston, J. T. (1972). Immunochemical studies on chlamydial group antigen (presence of a 2-keto-3deoxycarbohydrate as immunodominant group). Journal of Immunology 109, $116-122$.

Evans, R. T. \& TAYLOR-Robinson, D. (1979). Comparison of various $\mathrm{McC}$ oy cell treatment procedures used for detection of Chlamydia trachomatis. Journal of Clinical Microbiology 10, 198- 201.

Galanos, C., Llderitz. O. \& Westphal, O. (1969). A new method for the extraction of $\mathrm{R}$ lipopolysaccharide. European Journal of Biochemistry 9, 245249.

JANDA, J. \& WORK, E. (1971). A colorimetric estimation of lipopolysaccharide. FEBS Letters 16, 343345 .

Knox, K. W., Cullen, J. \& Work, E. (1967). An extracellular lipopolysaccharide-phospholipid-protein complex produced by Escherichia coli grown under lysine-limiting conditions. Biochemical Journal 103, 192.

LAEMMLI, U. K. (1970). Cleavage of structural proteins during the assembly of the head of bacteriophage T4 Nature, London 227, 680-685.

Nurminen, M., Leinonen, M., SaIKKu, P. \& Mäkelä, P. H. (1983). The genus specific antigen of Chlamydia: resemblance to the lipopolysaccharide of enteric bacteria. Sicience 220, 1279-1281
Nurminen, M., Wahlström, E., KleEmola, M., LEINONEN, M., SAIKKU, P. \& MÄKELÄ, P. (1984). Immunologically related ketodeoxyoctonate-containing structures in Chlamydia trachomatis, $\mathrm{Re}$ mutants of Salmonella species, and Acinetobacter calcoaceticus var. anitratus. Infection and Immunity. 44, 609-613.

Osborn. M. J. (1963). Studies on the Gram-negative cell wall. I. Evidence for the role of 2-keto-3deoxyoctonate in the LPS of Salmonella typhimurium. Proceedings of the National Academy of Sciences of the United States of America 50, 499-506.

Schachter, J. \& Dawson, C. R. (1978). Human Chlamydial Infections, 1st edn, pp. 210-212. Littleton, Mass., USA: PSG Publishing Co.

Scotr, M. L., Thornley, M. J., CoOmbs, R. R. A. \& Bradwell, A. R. (1981). Measurement of human serum $\operatorname{IgE}$ and $\operatorname{IgA}$ by reverse passive antiglobulin haemagglutination. International Archives of Allergy. and Applied Immunology 64, 222-229.

SCott, M. L., Merret, T. G., Ishizaka, K., ThorNLEY, M. J. \& COOMBS, R. R. A. (1982). Comparison of reverse passive haemagglutination with double antibody radioimmunoassay for estimation of total human serum IgE. Clinical and Experimental Immunology 48, 417-422.

Stephens, R. S., TAM, M. R., Kuo, C. C. \& Nowinski, R. C. (1982). Monoclonal antibodies to Chlamydia trachomatis: antibody specificities and antigen characterization. Journal of Immunology 128, 1083-1089.

Thornley, M. J., Lusher, M., SCOTT, M. L., COOMBS, R. R. A., Evans, R. T., Thomas, B. J. \& TaYlorRoBINSON, D. (1983). Characterization of a monoclonal antibody to the group antigen of Chlamydia spp. and its use for antigen detection by reverse passive haemagglutination and indirect immunofluorescence. FEMS Microbiology Letters 17, 45-49.

Towbin, H., Staehelin, T. \& Gordon, J. (1979). Electrophoretic transfer of proteins from polyacrylamide gels to nitrocellulose sheets: procedure and some applications. Proceedings of the National Academy of Sciences of the United States of America 79, 4350-4354.

TSaI, C. M. \& Frasch, C. E. (1982). A sensitive silver stain for detecting lipopolysaccharides in polyacrylamide gels. Analytical Biochemistry 119, 115-119.

WaldmanN, H. \& Milstein, C. (1982). Monoclonal antibodies. In Clinical Aspects of Immunology, 4th edn, pp. 476-503. Edited by P. J. Lachmann \& D. K. Peters, Oxford: Blackwell.

Westrhal, O. \& JanN, K. (1965). Bacterial lipopolysaccharides extraction with phenol-water and further application of the procedure. Methods in Carbohydrate Chemistry 5, 83\%91. 